\title{
Diabetes and restenosis
}

\author{
Scott Wilson ${ }^{1}$, Pasquale Mone ${ }^{1,2}$, Urna Kansakar ${ }^{1,2}$, Stanislovas S. Jankauskas ${ }^{1,2}$, Kwame Donkor ${ }^{1}$, \\ Ayobami Adebayo ${ }^{1}$, Fahimeh Varzideh ${ }^{1,2}$, Michael Eacobacci ${ }^{1}$, Jessica Gambardella ${ }^{2,3}$, Angela Lombardi ${ }^{1}$ and \\ Gaetano Santulli ${ }^{1,2,3^{*}}$ (]
}

\begin{abstract}
Restenosis, defined as the re-narrowing of an arterial lumen after revascularization, represents an increasingly important issue in clinical practice. Indeed, as the number of stent placements has risen to an estimate that exceeds 3 million annually worldwide, revascularization procedures have become much more common. Several investigators have demonstrated that vessels in patients with diabetes mellitus have an increased risk restenosis. Here we present a systematic overview of the effects of diabetes on in-stent restenosis. Current classification and updated epidemiology of restenosis are discussed, alongside the main mechanisms underlying the pathophysiology of this event. Then, we summarize the clinical presentation of restenosis, emphasizing the importance of glycemic control in diabetic patients. Indeed, in diabetic patients who underwent revascularization procedures a proper glycemic control remains imperative.
\end{abstract}

Keywords: ACS, BMS, CABG, DES, Diabetes, Endothelial dysfunction, Epidemiology, Hyperglycemia, PCl, Restenosis, STEMI, Stent, VSMC

\section{Introduction}

The global burden of cardiovascular disease is disproportionately borne by patients with diabetes mellitus (DM) [1-4]. Hyperglycemia, insulin-resistance, and the increased presence of advanced glycation end products (AGEs) represent a handful of the conditions that contribute to a 2 to fourfold increased risk of both coronary and peripheral artery disease (CAD \& PVD) in DM [5-10]. The deleterious effects of these components on the vascular endothelium have been shown in the literature to be closely associated with macrovascular disease including diffuse atherosclerosis [11-13]. However, it is the complications of diabetes-associated heart diseaseincluding vascular occlusion, restenosis, and in-stent

\footnotetext{
*Correspondence: gsantulli001@gmail.com

1 Department of Medicine, Einstein Institute for Aging Research, Einstein-Mount Sinai Diabetes Research Center (ES-DRC), The Fleischer Institute for Diabetes and Metabolism (FIDAM), Albert Einstein College of Medicine, New York, NY, USA

Full list of author information is available at the end of the article
}

restenosis (ISR) - that make diabetics a particularly complex population to treat.

Restenosis, defined as re-narrowing of an arterial lumen after corrective vascular intervention like percutaneous intervention (PCI) and coronary artery bypass graft surgery (CABG), is an increasingly important issue in clinical practice. Indeed, as the number of stent placements has risen to an estimate of over 3 million annually worldwide, revascularization procedures have become much more common. Unsurprisingly, it has been consistently shown that vessels in patients with DM have an accelerated rate of late loss of lumen diameter and increased ISR [14-16]. In fact, DM is an independent predictor of recurrent restenosis [17-19].

As we have come to realize, the progression of restenosis can be affected by our treatment choices: both for the underlying DM and in the type of intervention in the occluded vessel. With the advent of newer therapies and second-generation drug-eluting stents (DES), restenosis can be better managed than ever before. Herein, we will present a systematic overview of the effects of DM on original author(s) and the source, provide a link to the Creative Commons licence, and indicate if changes were made. The images or other third party material in this article are included in the article's Creative Commons licence, unless indicated otherwise in a credit line to the material. If material is not included in the article's Creative Commons licence and your intended use is not permitted by statutory regulation or exceeds the permitted use, you will need to obtain permission directly from the copyright holder. To view a copy of this licence, visit http://creativecommons.org/licenses/by/4.0/. The Creative Commons Public Domain Dedication waiver (http://creativeco mmons.org/publicdomain/zero/1.0/) applies to the data made available in this article, unless otherwise stated in a credit line to the data. 
ISR after coronary angioplasty. We searched in PubMed original clinical studies presenting in the title the words diabetes, in-stent restenosis, restenosis; studies not in English and abstracts were not included.

\section{Effects of diabetes on the cardiovascular system}

Despite the widespread use of hypoglycemic agents and greater awareness, diabetic patients experience significantly higher all-cause and cardiovascular mortality rates than subjects without diabetes after adjustment for other risk factors $(16 \%$ and $18 \%$, respectively in 2019) [20, 21]. Macrovascular complications mediated by atherosclerosis prove to be the leading cause of premature death in this population [22-24]. Nonetheless, microvascular complications can often present clinically in the form of diabetic nephropathy, neuropathy, and retinopathy [25-32]. A major contributor to both types of vasculopathy is endothelial damage, mediated in part by the actual glycemic control of each patient [33]. Hyperglycemia can contribute to oxidative stress through the production of mitochondrial superoxide, NADPH reduction through polyol accumulation, and AGE synthesis through the nonenzymatic oxidation of glycoproteins-all of which are capable to cause damage to the endothelial cells; the vascular endothelium is particularly sensitive to the effects of hyperglycemia since endothelial cells do not adaptively downregulate their GLUT-mediated uptake of glucose [34-37].

Diabetic cardiomyopathy represents the direct effect of diabetes on both the structure and function of the heart [7, 38, 39]. Even after adjustment for conventional risk factors (like age, CAD, dyslipidemia, and hypertension), those with diabetes have a markedly higher risk for the development of heart failure [7]. This cardiomyopathy typically presents left ventricular hypertrophy and diastolic dysfunction at the echocardiographic examination, often leading to heart failure with preserved ejection fraction (HFpEF, ejection fraction $\geq 50 \%$ ) [40, 41]. The mechanisms behind these changes are not fully understood but likely involve many of the processes common to those implicated in vascular endothelial damage, in addition to impaired mitochondrial calcium handling and autonomic neuropathy-all of which have been functionally linked to hyperglycemia $[42,43]$.

\section{Pathophysiology of restenosis \\ Definition}

ISR, based on its traditional definition, is a $\geq 50 \%$ luminal re-narrowing of an artery within or directly adjacent to the stented region after PCI, determined through angiography. The clinical definition of ISR includes the same angiographic criteria along with signs of ischemia and/or acute coronary syndrome (ACS); often requiring target lesion revascularization (TLR) [44]. Finally, recurrent ISR is defined as two or more revascularization failures at the same vascular segment.

\section{Overview}

The progression of restenosis is gradual, already starting in the early hours after intervention. Using PCI to restore blood flow in atherosclerotic vessels can result in the disruption of the target vessel's integrity. An intact endothelial lining is an important factor in preventing thrombosis, inflammation, and intimal hyperplasia. ISR occurs as a result of this endothelial damage and subsequent neointimal and vascular smooth muscle cell (VSMC) proliferation [45]. As early as $30 \mathrm{~min}$ after endothelial injury, proto-oncogenes have already begun to be upregulated in VSMC nuclei in response to growth factor signaling [46]. These processes form the basis of using pharmacologic agents to reduce cellular growth and migration in a stented vessel. If a stent is not used, however, like in the case of simple balloon angioplasty (BAP), restenosis is primarily mediated by the vessel elastic recoil followed by adverse remodeling [47-49].

Neointimal hyperplasia in patients with diabetes looks phenotypically different to the one observed in nondiabetic patients. VSMC specimens from patients with type 2 DM (T2DM) are phenotypically abnormal and behave in a more aggressive manner (greater adhesion and migration) in cell culture $[50,51]$. This process may be partly dependent on the adipokine resistin, which is upregulated in human aortic VSMCs in patients DM [52]. Furthermore, several studies have shown that proinflammatory cytokines (like IL-1 $\beta$, which is chronically activated in T2DM [53]) are able to induce the change in VSMCs into a secretory state, whereas both glucose and insulin could increase VSMC mitogenesis [54, 55]. These findings are consistent with accelerated rates of coronary narrowing and thrombosis in T2DM and highlight the importance of a tight glycemic control in these patients.

De novo neo-atherosclerosis may also be present in the site of the lesion, the progression of which-mainly mediated by chronic inflammation and low-density lipoprotein (LDL) cholesterol uptake by macrophages [56]might explain the presentation of unstable angina and thrombotic events in patients years after PCI [57]. Moreover, remnant-like particle cholesterol was shown to be an independent risk factor for ISR [58], whereas highdensity lipoprotein (HDL) cholesterol levels are known to be inversely associated with ISR in diabetic patients [59]. Other predictors of ISR include levels of soluble receptor for advanced glycation end products (sRAGE), uric acid, and platelet distribution width [60-63]. 
Neo-atherosclerosis is suggested to play a critical role in restenosis after the placement of a DES especially if compared to bare-metal stents (BMS) [64, 65]. Indeed, when comparing the two types of intervention, patients given a first-generation DES experienced a significantly earlier and more frequent onset of in-stent neo-atherosclerosis than those with BMS placement [66].

Patients with DM are subject to a unique, rapidly progressive, and widespread form of atherosclerosis, resulting in a higher rate of restenosis after simple BAP [67, 68]. These events increase the chance that a patient with DM will undergo repeated revascularizations, a procedure that has been shown to increase the risk of cardiovascular death fourfold ( $\mathrm{HR}=4.22$; 95\% CI, 2.10-8.48) in the 2020 Evaluation of XIENCE versus Coronary Artery Bypass Graft Surgery for Effectiveness of Left Main Revascularization (EXCEL) trial [69].

Impaired endothelial function and increased plasminogen activator inhibitor 1 (PAI-1) activity in patients with $\mathrm{DM}$ result in a greater risk of late in-stent thrombotic events after PCI, which is already more common with first-generation DES compared to BMS intervention [70]. Moreover, insulin-resistance contributes to increased $\mathrm{P}_{2} \mathrm{Y}$-receptor-pathway signaling, leading to greater platelet aggregation in DM [71]. These factors underscore the importance of adherence to dual antiplatelet therapy (DAPT, comprising of $\mathrm{P}_{2} \mathrm{Y}$-inhibitors and aspirin) in patients with DM undergoing PCI. In fact, patients who comply poorly with or cannot tolerate DAPT are likely to benefit more from alternatives to PCI including CABG, BAP, or medical therapy [72].

A major concern in modern stents is delayed failure in the form of late in-stent thrombosis, which is a thrombotic event occurring between 1 month and 1 year after PCI [73]. Although the incidence of late in-stent thrombosis is low ( $\sim 0.35 \%-0.7 \%$ in cases with DES), the outcomes are poor, with a fatality rate of $45 \%$ reported in 2005 and a fourfold increase in all-cause mortality $(\mathrm{HR}=4.9,95 \%$ CI 1.1-21.4) in 2009 [74-76]. Pathological studies of sirolimus and paclitaxel-eluting stents revealed that localized hypersensitivity against the stent polymer is a major thrombotic factor. Moreover, coronary arteries exhibit a longer delay in healing after DES implantation compared to BMS, consistent with reports of higher rates of very late ( $>1$ year) in-stent thrombosis in DES [77-79]. Chronic inflammation in response to the DES has shown to be a cause of this phenomenon, evidenced by persistent fibrin deposits and incomplete endothelization, particularly in patients with additional risk factors like DM. In this case, the suppression of neointimal expansion by sirolimus and paclitaxel may be detrimental-impairing the normal healing process of the vascular wall [80]. Thankfully, newer second-generation DES (including zotarolimus and everolimus-eluting stents) are associated with significantly lower rates of early and late in-stent thrombosis compared to sirolimus-eluting counterparts [81]. On top of these thromboresistant properties, everolimus-eluting stents were ranked as the most effective treatment for ISR according to a 2015 metaanalysis of 27 clinical trials in comparison to all other major modalities (in order of effectiveness: drug-coated balloons, first-generation DES, vascular brachytherapy, BMS, BAP, and rotablation) [82].

\section{ISR classification and risk factors}

There are three main categories of ISR defined by the Mehran System through angiographic classification: Pattern I (focal, $\leq 10 \mathrm{~mm}$ length), pattern II (diffuse, $>10 \mathrm{~mm}$ length), pattern III (proliferative, $>10 \mathrm{~mm}$, extending beyond the confines of the stent), and pattern IV (totally occluded ISR) [44]. These classifications can be regarded as a measure of a vessel's intrinsic proliferative response to stent placement. A study published in 1999 found that the long-term need for TLR increases with the higher classes of ISR $(H R=1.7 ; \mathrm{P}=0.0380)$ and with the presence of diabetes $(H R=2.8 ; P=0.0003)$ [83]. Taken together with other evidence, DM is suggested to be a strong determinant of neointimal hyperplasia [84, 85]. Other risk factors for ISR include pre-operative variables like vessel diameter, stent length, number of prior stents, age, hypertension, and kidney disease [86-89]. However, post-operative levels of inflammatory markers (including high-sensitivity C-reactive protein, matrix metalloproteinase 2, tumor necrosis factor, and chemokine ligand 2) also serve as potential risk criteria [90-93].

The distribution of neointimal proliferation is most often uniform along the length of the stent but may be focal, as shown by intravascular ultrasound [94]. Various studies have shown that the lesion's appearance can vary significantly with the type of stent used: notably, restenosis in BMS is generally more diffuse than in DES [95]. On the other hand, in-stent neointimal proliferation in patients with DM tends to be located more towards the edges of the stent [44].

Lastly, immunologic, genetic and epigenetic mechanisms have been proposed to partakes in the pathophysiology of ISR in diabetic patients [96-124].

\section{Epidemiology}

The incidence of restenosis varies significantly across studies. Rates have dropped markedly with technological advances in angioplasty. The occurrence of restenosis is estimated to be at about $32-55 \%$ in the pre-stent era, $17-41 \%$ in the BMS era (after their implementation in the 1980s), compared to less than $18 \%$ with the use 
of second-generation DES [47]. In support of these estimates, there has been a greatly decreased incidence of TLR and cardiovascular mortality in patients using DES over BMS. This estimate includes the use of first-generation sirolimus-eluting stent, in which the occurrence of ISR is comparably low following the procedure but more common in diabetic patients [125-127].

Karl Haase and collaborators determined that the small size of the vessel and the presence of DM were independent predictors for the occurrence of ISR [128]. Although the risk factors for ISR in the general population are welldefined, there have been fewer studies dedicated to the differences between diabetic patients that fall victim to restenosis versus those that do not. A recent prospective study of 920 diabetic patients found that serum VLDL$\mathrm{C}$ and uric acid were associated with a relative risk of ISR after coronary DES implantation of 1.85- and 1.19, respectively [129]. In this study, LDL-C and HDL-C levels were not significantly different between the two groups.

\section{Clinical presentation}

ISR may present as recurrent signs of myocardial ischemia-often beginning with stable angina pectoris as shown through patient history, stress tests, and ECG modifications [130,131]. Though, this presentation may be a result of incomplete revascularization or the progression of CAD at a separate site [44]. Rather, the definitive diagnosis of ISR is normally made through coronary angiography [132-135].

Symptoms have been found to develop on an average of about 6 months after PCI in patients with ISR of a BMS. Those with DES generally develop symptoms later, but often between 3 and 12 months and have a more stable symptomatology $[44,136]$. Nonetheless, restenosis cannot be seen as a benign condition. ACS arising from ISR is well documented and associated with more adverse cardiac outcomes [137, 138]. A 2014 retrospective study found that of 909 patients undergoing TLR from prior PCI with all generations of stents-including second-generation DESs - the majority presented with ACS at $66-71 \%$ [139]. Yet, statistics on the presentation of ISR can vary greatly between studies with many finding that patients with ISR are most commonly asymptomatic or present with stable angina in the DES era [140]. Notably, approximately $50 \%$ of patients with restenosis determined initially by angiography have no ISR-related symptoms [141].

\section{Clinical data}

\section{Stent efficacy}

Ever since Eric Van Belle and colleagues reported no significant increase in ISR risk in diabetic patients in 1997 [142], a preponderant evidence has emerged showing that there is indeed an increased rate of ISR, TLR, ST, and major adverse cardiovascular events (MACE) due to DM when using BAP, BMS, and first-generation DES [68, 143]. Moreover, diabetic patients showed a more heterogenous pattern of the neointima after BMS, resulting in longer high-grade obstruction segments [144]. However, in the second-generation DES era, it remains somewhat controversial [145-151] whether DM (particularly $\mathrm{T} 2 \mathrm{DM}$ ) is still a statistically significant predictor of longterm adverse outcomes-including ISR, MACE, and late in-stent thrombosis after PCI (Table 1). This uncertainty may reflect the fact that the use of second-generation DES suppresses the difference in outcomes between those with and without DM. Though, the variability may be partly caused by differences in clinical variables (such as secondary prevention), study design, and stent components (including alloy and drug delivery vehicle).

In any case, there is a clear benefit of using newer-generation stent technology over first-generation DES on ISR when looking exclusively at patients with DM. This finding was shown initially in the Everolimus-Eluting Stent Versus Sirolimus-Eluting Stent Implantation for De Novo Coronary Artery Disease in Patients with Diabetes Mellitus (ESSENCE-DIABETES) prospective trial in 2011 and confirmed by lengthier studies that followed [152, 153]. Notably, four years later, the Taxus Element versus Xience Prime in a Diabetic Population (TUXEDO)-India study demonstrated that there was a significantly greater incidence of TLR $(3.4 \%$ vs. $1.2 \%, \mathrm{P}=0.002)$, in-stent thrombosis ( $2.1 \%$ vs. $0.4 \%, \mathrm{P}=0.002)$, and spontaneous myocardial infarction (MI, $3.2 \%$ vs. $1.2 \%, \mathrm{P}=0.004$ ) after 1 year in diabetic patients randomized to the paclitaxeleluting stent intervention [154]. A more recent retrospective study stratified 13,895 patients with prior MI into normoglycemic, pre-diabetic, and diabetic groups to compare outcomes between first and second-generation DES intervention. The authors found a significantly higher incidence of cardiovascular endpoint and in-stent thrombosis in those treated with first-generation in comparison to second-generation DES within all three glycemic groups [155]. This confirmation is important since prior evidence of the relative benefits of newer DES generations in DM patients post-MI was limited.

When comparing first-generation paclitaxel- and sirolimus-eluting stents specifically in patients with DM, data diverge on the relative risk of MACE of each; these two stent types tend to be comparable in safety profile with sirolimus-eluting stent intervention likely resulting in slightly lower ISR rates over paclitaxel-eluting counterparts according to meta-analyses $[156,157]$.

Drug-coated balloons (DCBs) and bioabsorbable vascular scaffolds (BVSs) are two modern interventions similar in that they deliver an anti-proliferative agent to the 
Table 1 Relative risk of major adverse cardiac events (MACE), target lesion revascularization (TLR), and stent thrombosis (ST) in patients with and without DM undergoing PCI with second-generation drug-eluting stent (DES)

\begin{tabular}{|c|c|c|c|c|c|c|c|c|}
\hline Study & Study design & $\begin{array}{l}\text { Number } \\
\text { of diabetic } \\
\text { patients }\end{array}$ & Total patients & $\begin{array}{l}\text { T1DM } \\
\text { and/or } \\
\text { T2DM }\end{array}$ & Outcome & $\begin{array}{l}\text { Relative risk } \\
\text { (95\% confidence } \\
\text { interval) }\end{array}$ & P-value & References \\
\hline \multirow[t]{4}{*}{ Konishi et al. (2016) } & \multirow{4}{*}{$\begin{array}{l}\text { Observational cohort } \\
\text { study } \\
\text { Mean follow-up: } \\
958 \text { days }\end{array}$} & 575 & 1667 & T1DM & MACE & $1.18(0.74-1.82)^{*}$ & 0.48 & \multirow[t]{4}{*}{ [145] } \\
\hline & & 199 & 1291 & T2DM & MACE & $1.07(0.77-1.49)^{*}$ & 0.67 & \\
\hline & & 575 & 1667 & T1DM & TLR & $1.92(1.10-3.29)^{*}$ & 0.02 & \\
\hline & & 199 & 1291 & T2DM & TLR & $1.52(0.97-2.35)^{*}$ & 0.06 & \\
\hline $\begin{array}{l}\text { D'Ascenzo et al. } \\
\text { (2017) }\end{array}$ & $\begin{array}{l}\text { Retrospective multi- } \\
\text { center study } \\
\text { Mean follow-up: } \\
650 \text { days }\end{array}$ & 485 & 1270 & T1DM & TLR & $2.0(1.1-3.6)$ & 0.04 & {$[146]$} \\
\hline Honda et al. (2015) & $\begin{array}{l}\text { Retrospective single } \\
\text { center study } \\
\text { Mean follow-up: } \\
23.1 \text { months }\end{array}$ & 713 & 1669 & Both & TLR & $1.23(0.89-1.69)$ & 0.21 & [147] \\
\hline \multirow[t]{2}{*}{ Zheng et al. (2019) } & \multirow{2}{*}{$\begin{array}{l}\text { Retrospective single } \\
\text { center study } \\
\text { Mean follow-up: } \\
325 \text { days and } \\
772 \text { days }\end{array}$} & \multirow[t]{2}{*}{133} & \multirow[t]{2}{*}{394} & \multirow[t]{2}{*}{ Both } & Early TLR & $2.58(1.29-5.15)$ & 0.007 & \multirow[t]{2}{*}[148]{} \\
\hline & & & & & Late TLR & $1.56(0.47-5.21)$ & 0.472 & \\
\hline \multirow[t]{2}{*}{ Pi et al. (2018) } & \multirow{2}{*}{$\begin{array}{l}\text { Retrospective multi- } \\
\text { center study } \\
\text { Mean follow-up: } \\
3 \text { years }\end{array}$} & \multirow[t]{2}{*}{1786} & \multirow[t]{2}{*}{4812} & \multirow[t]{2}{*}{ Both } & TLR & $1.70(1.22-2.36)$ & 0.002 & \multirow[t]{2}{*}{ [149] } \\
\hline & & & & & ST & $1.55(0.75-3.21)$ & 0.242 & \\
\hline \multirow{3}{*}{$\begin{array}{l}\text { Kuramitsu et al. } \\
\text { (2019) }\end{array}$} & \multirow{3}{*}{$\begin{array}{l}\text { Retrospective multi- } \\
\text { center study } \\
\text { Mean follow-up: } \\
4 \text { years }\end{array}$} & \multirow[t]{3}{*}{695} & \multirow[t]{3}{*}{1541} & \multirow[t]{3}{*}{ Both } & Early ST & $1.20(0.81-1.77)$ & 0.36 & \multirow[t]{3}{*}{ [150] } \\
\hline & & & & & Late ST & $1.02(0.52-1.99)$ & 0.95 & \\
\hline & & & & & Very late ST & $0.93(0.51-1.71)$ & 0.83 & \\
\hline
\end{tabular}

Early TLR and late LTR were determined angiographically at the first ( $325 \pm 90$ days) follow-up and between the first and second ( $772 \pm 133$ days) follow-ups, respectively, in the Zheng et al. study. In the Kuramitsu et al. study, Early ST was classified as occurring within 30 days, Late ST was between 31 and 365 days, and Very Late ST referred to events after 1 year. ${ }^{*}=$ Multivariate analysis used. Bold text $=$ statistical significance at $p<0.05$

vascular endothelium without permanently adding additional scaffolds. DCBs have proven non-inferior to (and occasionally favorable over) first-generation DES, particularly in coronary small vessel disease. For example, a reduction in TLR was found only in diabetic patients in last year's Long-term Efficacy and Safety of Drug-Coated Balloons versus Drug-Eluting Stents for Small Coronary Artery Disease (BASKET-SMALL 2) trial [158, 159]. Meta-analysis of the limited studies on DCB in de-novo lesions in diabetic patients presented neutral findings over the use of DES [160]. However, the Restenosis Intrastent of Bare Metal Stents: Paclitaxel-eluting Balloon vs. Everolimus-eluting Stent (RIBS-IV) trial found that PCI with second-generation DES was associated with lower percent diameter stenosis over DCB (mean follow up of 1 year) [161]; still, the overall need for TLR in both groups was low and comparable, suggesting second-generation DES may be marginally preferable in the context of large vessel disease [161].

The Drug-Eluting Balloon for In-Stent Restenosis (DARE) trial was designed to investigate the relative performance of the paclitaxel-eluting balloon compared with the everolimus-eluting stent (XIENCE) in the treatment of any ISR [162]. In patients with ISR and DM, the Paclitaxel-eluting Balloon resulted in similar 6-months in-segment minimal lumen diameter and comparable rates of major adverse events compared to Xience, and in-segment late loss at 6 months was significantly lower in the Paclitaxel-eluting Balloon arm [163].

Despite the comprehensive evidence for using DES, BMS is still widely used for diabetic patients in the United States [164-167]. This fact may be attributed to both high prices and increased duration of DAPT needed for DES, despite beneficial cost-benefit analysis [168]. Both global and local gaps in access to these new therapies should be viewed as drivers in disparate cardiovascular outcomes between socioeconomic and ethnic groups as demonstrated by countless studies [169-173]. This aspect represents a considerable a problem for patients with diabetes, since they are at a significantly higher risk for revascularization with BMS over DES and tend to be stratified into lower socioeconomic groups [174, 175]. Indeed, these factors must be considered in advocating for patients and informing areas of research in the future. 


\section{Glycemic control}

Glycemic control at the time of PCI plays an essential role in preventing TLR [176-178]. Of note, fasting blood glucose and hemoglobin $\mathrm{A}_{1 \mathrm{c}}\left(\mathrm{HbA}_{1 \mathrm{c}}\right)$ have been thoroughly investigated as clinical biomarkers for ISR risk [179]. Results between studies often vary regarding the degree to which $\mathrm{HbA}_{1 \mathrm{c}}$ and fasting blood glucose correlated with restenosis in DM and/or metabolic syndrome. However, most authors present evidence that supports the importance of proper pre- and post-operative glycemic control. Recently, in a 2020 cohort study, 420 T2DM patients with DES were given follow-up coronary angiographies and routine $\mathrm{HbA}_{1 \mathrm{c}}$ measurements [180]. In this study, insulin resistance (known risk factor in ISR [181-188]) was correlated with higher tertiles of $\mathrm{HbA}_{1 \mathrm{c}}$ variability and, therefore, may have played a confounding role. Most recently, our group has demonstrated that hyperglycemia plays a decisive role in ISR, also in non-diabetic patients [189]. Indeed, we showed that admission hyperglycemia increased the risk of ISR at one year follow-up, both in BMS and 2nd generation DES [189]. Intriguingly, this effect was independent from glycemic control.

Hyperglycemia does also affect restenosis in vessels other than the coronary arteries [190-210]. For instance, a retrospective study of 322 patients undergoing carotid artery stenting reported that patients with elevated perioperative fasting blood glucose had significantly less freedom from restenosis at 5 years compared to those with normal fasting blood glucose [211].

\section{Hyperinsulinemia and restenosis}

Considering the other components of T2DM phenotype, insulin resistance and hyperinsulinemia are likely key players in the increased incidence of restenosis [212]. It is worth noting that multiple studies have linked measures of insulin resistance to the rate of ISR after coronary DES intervention [181, 184, 213, 214]. A 2015 cohort study revealed that the Homeostatic Model Assessment for Insulin Resistance (HOMA-IR) - a model using fasting plasma insulin and glucose [215-218] - could predict the risk of ISR in both diabetic and non-diabetic patients (HR 1.5, 95\% CI 1.2-1.8; p<0.001) [213, 219]. Several studies reported hyperinsulinemia as an independent risk factor for restenosis, even in patients in absence of DM or treatment with insulin [110, 220-222]. Furthermore, restenosis rates are found to be higher in diabetic populations with greater percentages of patients treated with insulin [223]. One explanation for these results is that high insulin levels are directly associated with both increased PAI-1 expression, which increases thrombosis and VSMC proliferation (characteristics of restenosis and late ST) [224].
The importance of strict glycemic control on cardiovascular complications in patients with T2DM is well-understood by the biomedical community. A 2009 meta-analysis of five large retrospective studies reported a $15 \%$ reduction in events related to $\mathrm{CAD}(\mathrm{HR}=0.85$, 95\% CI 0.77-0.93) in patients following a more intensive glucose-lowering regimen [225].

Various studies have suggested that using insulin-sensitizing (IS) strategies like metformin and thiazolidinediones have a more beneficial effect on restenosis than insulin-providing regimens using insulin therapy and sulfonylureas [50]. Moreover, the favorable effects of thiazolidinediones on the progression of restenosis have been demonstrated to be independent of glycemic control; this finding may be explained through their agonistic effect on PPAR $\gamma$, including the reduction of proinflammatory cytokines, VSMC migration, and neointimal hyperplasia (as measured by carotid arterial intima-media thickness) [226-228].

Clinical data on the effects of IS therapy are somewhat mixed. Numerous small studies have shown that troglitazone, pioglitazone, and rosiglitazone result in reduced restenosis compared to conventional therapy for DM [229-232]. Yet, in 2010, a major randomized control trial of 2368 patients found that those with stable ischemic heart disease and T2DM had a significant reduction in MI only with IS regimens (but not insulin-preserving regimens) post-CABG, with a decreased but non-significant reduction post-PCI [233]. A large retrospective study found that although metformin and thiazolidinedionesindividually_did not significantly reduce mortality over the standard of care, co-prescription of the two IS treatments was able to reduce cardiac endpoint $(\mathrm{HR}=0.52$, 95\% CI 0.34-0.82) within 1 year [234]. Further investigation on the clinical efficacy of IS therapy is merited and treatment strategies using combinations of agents may be a promising direction.

\section{Pharmacological prevention}

Beyond general glycemic control, DAPT and lipid-lowering therapy form the pillars of treatment after the placement of a stent in diabetic patients [235]. Some studies have indicated that the addition of cilostazol to these agents (sometimes referred to as triple antiplatelet therapy') may decrease the risk of ISR [236-238]. Cilostazol is a vasodilator that suppresses cAMP degradation, a substance whose anti-mitogenic properties have been found to maintain VSMC quiescence in damaged vessels [239]. Reassuringly, a reduction in both late lumen loss and 9-month TLR was observed in cilostazol-treated diabetic patients receiving DES in a recent prospective study [240]. For diabetic patients that cannot receive DES, 
administration of colchicine has proven to be very effective in reducing the rate of ISR in BMS [241].

The use of antioxidants in ISR has been evaluated for over a decade, taking into account that restenosis is partly mediated by oxidative stress to the vascular endothelium-particularly in presence of hyperglycemia [242-249]. Substances that reduce free radicals like probucol have shown promise in vitro, but are marred by side-effects, including prolongation of QT-interval [250].

While the results of related clinical trials come in, perhaps the most straightforward path to prevention is adequate management of DM itself.

\section{Conclusions}

Available evidence indicates that a tight glycemic control is crucial in diabetic patients who underwent revascularization procedures. Current treatment paradigms for DM should not be cast aside to better manage alterations in insulinemia, but it should be noted that the choice of glucose-lowering agent may affect the chances of developing ISR.

\section{Acknowledgements}

We thank Dr. Wang for helpful discussion. We apologize to the authors whose contributions were not directly cited.

\section{Authors' contributions}

All authors wrote the main manuscript text and reviewed the manuscript. All authors fully contributed to this research. All authors read and approved the final manuscript.

\section{Funding}

The Santulli laboratory is supported in part by the National Institutes of Health (R01-HL146691, R01-DK123259, R01-DK033823, R01-HL159062, R56-AG066431، and T32-HL144456 to G.S.), by the Irma T. Hirschl and Monique Weill-Caulier Trusts (to G.S.), by the Diabetes Action Research and Education Foundation (to G.S.), by the New York Academy of Medicine (NYAM, Glorney-Raisbeck Grant in Cardiovascular Medicine to S.W.), and by the American Heart Association (AHA-21POST836407 to S.J.J., and AHA-22POST915561 to F.V., and AHA2OPOST35211151 to J.G.).

\section{Availability of data and materials \\ Not applicable.}

\section{Declarations}

\section{Ethics approval and consent to participate}

Not applicable.

\section{Consent for publication}

All authors gave the consent for the publication of the article. All data and materials are available.

\section{Competing interests}

The authors declare no competing interests.

\section{Author details}

'Department of Medicine, Einstein Institute for Aging Research, Einstein-Mount Sinai Diabetes Research Center (ES-DRC), The Fleischer Institute for Diabetes and Metabolism (FIDAM), Albert Einstein College of Medicine, New York, NY, USA. ${ }^{2}$ Department of Molecular Pharmacology, Wilf Family Cardiovascular Research Institute, Institute for Neuroimmunology and Inflammation (INI),, Albert Einstein College of Medicine, New York, NY, USA.
${ }^{3}$ International Translational Research and Medical Education (ITME) Consortium, Department of Advanced Biomedical Sciences, "Federico II" University, Naples, Italy.

Received: 16 December 2021 Accepted: 21 January 2022

Published online: 14 February 2022

\section{References}

1. Draznin B, Aroda VR, Bakris G, Benson G, Brown FM, Freeman R, Green J, Huang E, Isaacs D, Kahan S, et al. Cardiovascular disease and risk management: standards of medical care in diabetes-2022. Diabetes Care. 2022;45(Supplement_1):S144-74.

2. Cahn A, Wiviott SD, Mosenzon O, Goodrich EL, Murphy SA, Yanuv I, Rozenberg A, Bhatt DL, Leiter LA, McGuire DK et al. Association of baseline $\mathrm{HbA} 1 \mathrm{c}$ with cardiovascular and renal outcomes: analyses from DECLARE-TIMI 58. Diabetes Care 2022.

3. Chen S, Huang Z, Chen L, Zhao X, Kang Y, Lai W, Lu X, Zhou Y, He Y, Huang $H$, et al. Does diabetes mellitus increase the short- and longterm mortality in patients with critical acute myocardial infarction? Results from American MIMIC-III and Chinese CIN cohorts. Front Endocrinol (Lausanne). 2021;12:797049.

4. Einarson TR, Acs A, Ludwig C, Panton UH. Prevalence of cardiovascular disease in type 2 diabetes: a systematic literature review of scientific evidence from across the world in 2007-2017. Cardiovasc Diabetol. 2018;17(1):83.

5. Fishman SL, Sonmez H, Basman C, Singh V, Poretsky L. The role of advanced glycation end-products in the development of coronary artery disease in patients with and without diabetes mellitus: a review. Mol Med. 2018;24(1):59.

6. Ruiz HH, Ramasamy R, Schmidt AM. Advanced glycation end products: building on the concept of the "Common Soil" in metabolic disease. Endocrinology. 2020; 161(1).

7. Jankauskas SS, Kansakar U, Varzideh F, Wilson S, Mone P, Lombardi A, Gambardella J, Santulli G. Heart failure in diabetes. Metabolism 2021:154910.

8. Shu J, Matarese A, Santulli G. Diabetes, body fat, skeletal muscle, and hypertension: the ominous chiasmus? J Clin Hypertens (Greenwich). 2019;21(2):239-42.

9. Vlassara H, Uribarri J. Advanced glycation end products (AGE) and diabetes: cause, effect, or both? Curr Diab Rep. 2014;14(1):453.

10. Shu J, Santulli G. Update on peripheral artery disease: epidemiology and evidence-based facts. Atherosclerosis. 2018;275:379-81.

11. Aronson D, Rayfield EJ. How hyperglycemia promotes atherosclerosis: molecular mechanisms. Cardiovasc Diabetol. 2002;1(1):1.

12. Stolar MW. Atherosclerosis in diabetes: the role of hyperinsulinemia. Metabolism. 1988;37(2):1-9.

13. Mone P, Pansini A, Rizzo M, Minicucci F, Mauro C. St-elevation myocardial infarction patients with hyperglycemia: effects of intravenous adenosine. Am J Med Sci. 2021.

14. Carrozza JP, Kuntz RE, Fishman RF, Baim DS. Restenosis after arterial injury caused by coronary stenting in patients with diabetes mellitus. Ann Intern Med. 1993;1 18(5):344-9.

15. Sobel BE. Acceleration of restenosis by diabetes. Circulation. 2001;103(9):1185-7.

16. Paramasivam G, Devasia T, Jayaram A, Rao MS, Vijayvergiya R, Nayak K In-stent restenosis of drug-eluting stents in patients with diabetes mellitus: clinical presentation, angiographic features, and outcomes. Anatol J Cardiol. 2020;23(1):28-34.

17. Airoldi F, Briguori C, lakovou I, Stankovic G, Biondi-Zoccai G, Carlino M, Chieffo A, Montorfano M, Cosgrave J, Michev I, et al. Comparison of sirolimus versus paclitaxel eluting stents for treatment of coronary in-stent restenosis. Am J Cardiol. 2006;97(8):1182-7.

18. Alfonso F, Byrne RA, Rivero F, Kastrati A. Current treatment of in-stent restenosis. J Am Coll Cardiol. 2014;63(24):2659-73.

19. Zhao L, Zhu W, Zhang X, He D, Guo C. Effect of diabetes mellitus on long-term outcomes after repeat drug-eluting stent implantation for in-stent restenosis. BMC Cardiovasc Disord. 2017;17(1):16.

20. Tachkov K, Mitov K, Koleva Y, Mitkova Z, Kamusheva M, Dimitrova M, Petkova V, Savova A, Doneva M, Tcarukciev D, et al. 
Life expectancy and survival analysis of patients with diabetes compared to the non diabetic population in Bulgaria. PLOS ONE. 2020;15(5):e0232815-e0232815.

21. Bertoni AG, Krop JS, Anderson GF, Brancati FL. Diabetes-related morbidity and mortality in a national sample of U.S. elders. Diabetes Care. 2002;25(3):471.

22. Dokken BB. The pathophysiology of cardiovascular disease and diabetes: beyond blood pressure and lipids. Diabetes Spectrum. 2008:21(3):160.

23. Baena-Díez JM, Peñafiel J, Subirana I, Ramos R, Elosua R, Marín-Ibañez A Guembe MJ, Rigo F, Tormo-Díaz MJ, Moreno-Iribas C, et al. Risk of causespecific death in individuals with diabetes: a competing risks analysis. Diabetes Care. 2016;39(11):1987.

24. Maiorino MI, Longo M, Scappaticcio L, Bellastella G, Chiodini P, Esposito K, Giugliano D. Improvement of glycemic control and reduction of major cardiovascular events in 18 cardiovascular outcome trials: an updated meta-regression. Cardiovasc Diabetol. 2021;20(1):210.

25. Girard E, Nacher M, Bukasa-Kakamba J, Fahrasmane A, Adenis A, Massicard M, Drak Alsibai K, De Toffol B, Bekima R, Thelusme L, et al. Vitamin $D$ deficiency in patients with diabetes in french guiana: epidemiology and relation with microvascular and macrovascular complications. Nutrients. 2021:13(12):4302.

26. Arnold SV, Khunti K, Tang F, Chen H, Cid-Ruzafa J, Cooper A, Fenici P, Gomes MB, Hammar N, Ji L, et al. Incidence rates and predictors of microvascular and macrovascular complications in patients with type 2 diabetes: results from the longitudinal global discover study. Am Heart J. 2022:243:232-9.

27. Ebadi SA, Pajavand H, Asadi A, Asadollahi P, Fatollahzadeh M. Relationship of musculoskeletal diseases with microvascular and macrovascular complications in patients with diabetes in Iran. Diabetes Metab Syndr. 2021;15(6):102272.

28. Tu CL, Sue SP, Hsu WH, Huang HY, Wen WL, Lin IT, Chen KH, Sheu NW, Huang SH, Lee MY. Causes of in-hospital death in patients with type 2 diabetes with microvascular and macrovascular complications in Taiwan. Int J Clin Pract. 2021;75(10):e14491.

29. Polemiti E, Baudry J, Kuxhaus O, Jager S, Bergmann MM, Weikert C, Schulze MB. BMI and BMI change following incident type 2 diabetes and risk of microvascular and macrovascular complications: the EPICPotsdam study. Diabetologia. 2021;64(4):814-25.

30. Muzurovic E, Kraljevic I, Solak M, Dragnic S, Mikhailidis DP. Homocysteine and diabetes: role in macrovascular and microvascular complications. J Diabetes Complications. 2021;35(3):107834.

31. Sun B, Luo Z, Zhou J. Comprehensive elaboration of glycemic variability in diabetic macrovascular and microvascular complications. Cardiovasc Diabetol. 2021;20(1):9.

32. An J, Nichols GA, Qian L, Munis MA, Harrison TN, Li Z, Wei R, Weiss T, Rajpathak S, Reynolds K. Prevalence and incidence of microvascular and macrovascular complications over 15 years among patients with incident type 2 diabetes. BMJ Open Diabetes Res Care. 2021;9(1):e001847.

33. Fowler MJ. Microvascular and macrovascular complications of diabetes. Clin Diabetes. 2008;26(2):77

34. Santulli G. Tirzepatide versus Semaglutide once weekly in Type 2 Diabetes. N Engl J Med. 2022; in press.

35. Kaiser N, Sasson S, Feener EP, Boukobza-Vardi N, Higashi S, Moller DE, Davidheiser S, Przybylski RJ, King GL. Differential regulation of glucose transport and transporters by glucose in vascular endothelial and smooth muscle cells. Diabetes. 1993;42(1):80-9.

36. Santulli G, Wronska A, Uryu K, Diacovo TG, Gao M, Marx SO, Kitajewski J, Chilton JM, Akat KM, TuschI T, et al. A selective microRNA-based strategy inhibits restenosis while preserving endothelial function. J Clin Invest. 2014;124(9):4102-14.

37. Stocca A, O'Toole D, Hynes N, Hynes SO, Mashayekhi K, McGinley L, O'Connell E, Coleman C, Sultan S, Duffy A, et al. A role for MRP8 in in stent restenosis in diabetes. Atherosclerosis. 2012;221(2):325-32.

38. Wang J, Song Y, Wang Q, Kralik PM, Epstein PN. Causes and characteristics of diabetic cardiomyopathy. Rev Diabet Stud. 2006;3(3):108-17.

39. Holscher ME, Bode C, Bugger H. Diabetic cardiomyopathy: does the type of diabetes matter? Int J Mol Sci. 2016;17(12):2136.

40. Jia G, Hill MA, Sowers JR. Diabetic cardiomyopathy: an update of mechanisms contributing to this clinical entity. Circ Res. 2018;122(4):624-38.
41. Lorenzo-Almorós A, Tuñón J, Orejas M, Cortés M, Egido J, Lorenzo Ó. Diagnostic approaches for diabetic cardiomyopathy. Cardiovasc Diabetol. 2017;16(1):28

42. Borghetti G, von Lewinski D, Eaton DM, Sourij H, Houser SR, Wallner M. Diabetic cardiomyopathy: current and future therapies. Beyond glycemic control. Front Physiol. 2018;9:1514.

43. Galderisi M. Diastolic dysfunction and diabetic cardiomyopathy: evaluation by Doppler echocardiography. J Am Coll Cardiol. 2006:48(8):1548-51.

44. Alraies MC, Darmoch F, Tummala R, Waksman R. Diagnosis and management challenges of in-stent restenosis in coronary arteries. World J Cardiol. 2017:9(8):640-51.

45. Kansakar U, Jankauskas SS, Gambardella J, Santulli G. Targeting the phenotypic switch of vascular smooth muscle cells to tackle atherosclerosis. Atherosclerosis. 2021;324:117-20.

46. Bauters C, de Groote P, Adamantidis M, Delcayre C, Hamon M, Lablanche JM, Bertrand ME, Dupuis B, Swynghedauw B. Proto-oncogene expression in rabbit aorta after wall injury. First marker of the cellular process leading to restenosis after angioplasty? Eur Heart J. 1992;13(4):556-9.

47. Buccheri D, Piraino D, Andolina G, Cortese B. Understanding and managing in-stent restenosis: a review of clinical data, from pathogenesis to treatment. J Thorac Dis. 2016;8(10):E1150-62.

48. Costa MA, Simon DI. Molecular basis of restenosis and drug-eluting stents. Circulation. 2005;111(17):2257-73.

49. Ward MR, Pasterkamp G, Yeung AC, Borst C. Arterial remodeling Mechanisms and clinical implications. Circulation. 2000;102(10):1186-91.

50. Lexis CPH, Rahel BM, Meeder JG, Zijlstra F, van der Horst ICC. The role of glucose lowering agents on restenosis after percutaneous coronary intervention in patients with diabetes mellitus. Cardiovasc Diabetol. 2009:8(1):41.

51. Faries PL, Rohan DI, Takahara H, Wyers MC, Contreras MA, Quist WC, King GL, LoGerfo FW. Human vascular smooth muscle cells of diabetic origin exhibit increased proliferation, adhesion, and migration. J Vasc Surg. 2001;33(3):601-7.

52. Calabro P, Samudio I, Willerson JT, Yeh ETH. Resistin promotes smooth muscle cell proliferation through activation of extracellular signalregulated kinase 1/2 and phosphatidylinositol 3-kinase pathways. Circulation. 2004;110(21):3335-40.

53. Herder C, Dalmas E, Boni-Schnetzler M, Donath MY. The IL-1 pathway in type 2 diabetes and cardiovascular complications. Trends Endocrinol Metab. 2015;26(10):551-63.

54. Herder C, Dalmas E, Böni-Schnetzler M, Donath MY. The IL-1 pathway in type 2 diabetes and cardiovascular complications. Trends Endocrinol Metab. 2015;26(10):551-63.

55. Avena R, Mitchell ME, Neville RF, Sidawy AN. The additive effects of glucose and insulin on the proliferation of infragenicular vascular smooth muscle cells. J Vasc Surg. 1998;28(6):1033-8.

56. Wolf D, Ley K. Immunity and Inflammation in Atherosclerosis. Circ Res. 2019;124(2):315-27.

57. Tsigkas GG, Karantalis V, Hahalis G, Alexopoulos D. Stent restenosis, pathophysiology and treatment options: a 2010 update. Hellenic J Cardiol. 2011;52(2):149-57.

58. Qin Z, Zhou K, Li YP, Wang JL, Cheng WJ, Hu CP, Shi C, He H, Zhou YJ. Remnant lipoproteins play an important role of in-stent restenosis in type 2 diabetes undergoing percutaneous coronary intervention: a single-centre observational cohort study. Cardiovasc Diabetol. 2019;18(1):11.

59. Sukhija R, Aronow WS, Sureddi R, Aleti S, Molavi B, Sachdeva R, Mehta $J$ L. Predictors of in-stent restenosis and patient outcome after percutaneous coronary intervention in patients with diabetes mellitus. Am J Cardiol. 2007;100(5):777-80.

60. Park HJ, Seo SM, Shin WS, Kim HY, Choi YS, Koh YS, Youn SG, Park MW, Chang K, Kim PJ, et al. Soluble receptor for advanced glycation end products is associated with in-stent restenosis in patients with type 2 diabetes with drug-eluting coronary stents. Coron Artery Dis. 2011;22(1):12-7.

61. Hu CP, Du Y, Zhu Y, Shi C, Qin Z, Zhao YX. Platelet distribution width on admission predicts in-stent restenosis in patients with coronary artery disease and type 2 diabetes mellitus treated with percutaneous coronary intervention. Chin Med J (Engl). 2018;131(7):757-63. 
62. Wang JL, Qin Z, Wang ZJ, Shi DM, Liu YY, Zhao YX, Yang LX, Cheng WJ, Zhou YJ. New predictors of in-stent restenosis in patients with diabetes mellitus undergoing percutaneous coronary intervention with drugeluting stent. J Geriatr Cardiol. 2018;15(2):137-45

63. Li S, Luo C, Chen H. Risk factors of in-stent restenosis in patients with diabetes mellitus after percutaneous coronary intervention: a protocol for systematic review and meta-analysis. Medicine (Baltimore). 2021;100(15):e25484.

64. Zhang BC, Karanasos A, Regar E. OCT demonstrating neoatherosclerosis as part of the continuous process of coronary artery disease. Herz. 2015;40(6):845-54.

65. Looser PM, Kim LK, Feldman DN. In-stent restenosis: pathophysiology and treatment. Curr Treat Options Cardiovasc Med. 2016;18(2):10.

66. Nakazawa G, Otsuka F, Nakano M, Vorpahl M, Yazdani SK, Ladich E, Kolodgie FD, Finn AV, Virmani R. The pathology of neoatherosclerosis in human coronary implants: bare-metal and drug-eluting stents. J Am Coll Cardiol. 2011;57(11):1314-22.

67. Aronson D, Edelman ER. Revascularization for coronary artery disease in diabetes mellitus: angioplasty, stents and coronary artery bypass grafting. Rev Endocr Metab Disord. 2010;11(1):75-86.

68. Van Belle E, Bauters C, Hubert E, Bodart J-C, Abolmaali K, Meurice T, McFadden EP, Lablanche J-M, Bertrand ME. Restenosis rates in diabetic patients. Circulation. 1997;96(5):1454-60.

69. Alhejily WA, Ohman EM. Repeat revascularization after PCI. Circ Cardiovasc Interv. 2012;5(6):746-7.

70. Magnani $\mathrm{G}$, Valgimigli $\mathrm{M}$. Dual antiplatelet therapy after drug-eluting stent implantation. Interv Cardiol (London, England). 2016;11 (1):51-3.

71. Ferreira IA, Mocking AIM, Feijge MAH, Gorter G, van Haeften TW, Heemskerk JWM, Akkerman J-WN. Platelet inhibition by insulin is absent in type 2 diabetes mellitus. Arterioscler, Thromb, Vasc Biol. 2006;26(2):417-22.

72. Grines CL, Bonow RO, Casey DE, Gardner TJ, Lockhart PB, Moliterno DJ, O'Gara P, Whitlow P. Prevention of premature discontinuation of dual antiplatelet therapy in patients with coronary artery stents. Circulation. 2007;115(6):813-8.

73. Windecker S, Meier B. Late coronary stent thrombosis. Circulation. 2007;116(17):1952-65

74. lakovou I, Schmidt T, Bonizzoni E, Ge L, Sangiorgi GM, Stankovic G, Airoldi F, Chieffo A, Montorfano M, Carlino M, et al. Incidence, predictors, and outcome of thrombosis after successful implantation of drugeluting stents. JAMA. 2005;293(17):2126-30.

75. Ong ATL, MCFadden EP, Regar E, de Jaegere PPT, van Domburg RT, Serruys PW. Late angiographic stent thrombosis (LAST) events with drug-eluting stents. J Am Coll Cardiol. 2005;45(12):2088-92.

76. Kukreja N, Onuma Y, Garcia-Garcia HM, Daemen J, van Domburg R, Serruys PW. The risk of stent thrombosis in patients with acute coronary syndromes treated with bare-metal and drug-eluting stents. JACC Cardiovasc Interv. 2009;2(6):534-41.

77. Joner M, Finn AV, Farb A, Mont EK, Kolodgie FD, Ladich E, Kutys R, Skorija K, Gold HK, Virmani R. Pathology of drug-eluting stents in humans: delayed healing and late thrombotic risk. J Am Coll Cardiol. 2006:48(1):193-202.

78. Kastrati A, Mehilli J, Pache J, Kaiser C, Valgimigli M, Kelbæk H, Menichelli M, Sabaté M, Suttorp MJ, Baumgart D, et al. Analysis of 14 trials comparing sirolimus-eluting stents with bare-metal stents. N Engl J Med. 2007;356(10):1030-9.

79. Stone GW, Moses JW, Ellis SG, Schofer J, Dawkins KD, Morice MC, Colombo A, Schampaert E, Grube E, Kirtane AJ, et al. Safety and efficacy of sirolimus- and paclitaxel-eluting coronary stents. N Engl J Med. 2007;356(10):998-1008.

80. Zhang Q, Lu L, Pu L, Zhang R, Shen J, Zhu Z, Hu J, Yang Z, Chen Q, Shen W. Neointimal hyperplasia persists at six months after sirolimus-eluting stent implantation in diabetic porcine. Cardiovasc Diabetol. 2007;6:16.

81. Lange RA, Hillis LD. Second-generation drug-eluting coronary stents. N Engl J Med. 2010;362(18):1728-30.

82. Siontis GCM, Stefanini GG, Mavridis D, Siontis KC, Alfonso F, Pérez Vizcayno MJ, Byrne RA, Kastrati A, Meier B, Salanti G, et al. Percutaneous coronary interventional strategies for treatment of in-stent restenosis: a network meta-analysis. The Lancet. 2015;386(9994):655-64.
83. Mehran R, Dangas G, Abizaid AS, Mintz GS, Lansky AJ, Satler LF, Pichard $A D$, Kent KM, Stone GW, Leon MB. Angiographic patterns of in-stent restenosis. Circulation. 1999;100(18):1872-8.

84. Liu MW, Roubin GS, King SB 3rd. Restenosis after coronary angioplasty. Potential biologic determinants and role of intimal hyperplasia. Circulation. 1989;79(6):1374-87.

85. Abizaid A, Kornowski R, Mintz GS, Hong MK, Abizaid AS, Mehran R, Pichard AD, Kent KM, Satler LF, Wu H, et al. The influence of diabetes mellitus on acute and late clinical outcomes following coronary stent implantation. J Am Coll Cardiol. 1998;32(3):584-9.

86. Texakalidis P, Tzoumas A, Giannopoulos S, Jonnalagadda AK, Jabbour P, Rangel-Castilla L, Machinis T, Rivet DJ, Reavey-Cantwell J. Risk factors for restenosis after carotid revascularization: a meta-analysis of hazard ratios. World Neurosurg. 2019;125:414-24.

87. Mone P, Gambardella J, Pansini A, de Donato A, Martinelli G, Boccalone E, Matarese A, Frullone S, Santulli G. Cognitive impairment in frail hypertensive elderly patients: role of hyperglycemia. Cells. 2021;10(8):2115.

88. Mone P, Gambardella J, Pansini A, Rizzo M, Mauro C, Minicucci F, Santulli G. Impact of thrombus aspiration in frail STEMI patients. Aging Clin Exp Res. 2021;33:3071.

89. Mone P, Gambardella J, Pansini A, Martinelli G, Minicucci F, Mauro C, Santulli G. Cognitive dysfunction correlates with physical impairment in frail patients with acute myocardial infarction. Aging Clin Exp Res. 2021;34:49.

90. Cheng G, Chang F-J, Wang Y, You P-H, Chen H-C, Han W-Q, Wang J-W, Zhong N-E, Min Z-Q. Factors influencing stent restenosis after percutaneous coronary intervention in patients with coronary heart disease: a clinical trial based on 1-year follow-up. Med Sci Monit. 2019;25:240-7.

91. Cho JY. Identification of risk factors influencing in-stent restenosis with acute coronary syndrome presentation. Chonnam Med J. 2017;53(3):203-10.

92. Tang L, Cui Q-W, Liu D-P, Fu Y-Y. The number of stents was an independent risk of stent restenosis in patients undergoing percutaneous coronary intervention. Medicine. 2019;98(50):e18312.

93. Angioi M, Abdelmouttaleb I, Rodriguez R-M, Aimone-Gastin I, Adjalla C, Guéant J-L, Danchin N. Increased C-reactive protein levels in patients with in-stent restenosis and its implications. Am J Cardiol. 2001;87(10):1189-93.

94. Hoffmann R, Mintz GS, Dussaillant GR, Popma JJ, Pichard AD, Satler LF, Kent KM, Griffin J, Leon MB. Patterns and mechanisms of instent restenosis. A serial intravascular ultrasound study. Circulation. 1996:94(6):1247-54

95. Nam C-W, Rha S-W, Koo B-K, Doh J-H, Chung W-Y, Yoon M-H, Tahk S-J, Lee B-K, Lee J-B, Yoo K-D, et al. Usefulness of coronary pressure measurement for functional evaluation of drug-eluting stent restenosis. Am J Cardiol. 2011:107(12):1783-6.

96. Weng R, Liu S, Gu X, Zhong Z. Clonal diversity of the B cell receptor repertoire in patients with coronary in-stent restenosis and type 2 diabetes. Open Life Sci. 2021;16(1):884-98.

97. Guneri S, Baris N, Aytekin D, Akdeniz B, Pekel N, Bozdemir V. The relationship between angiotensin converting enzyme gene polymorphism, coronary artery disease, and stent restenosis: the role of angiotensin converting enzyme inhibitors in stent restenosis in patients with diabetes mellitus. Int Heart J. 2005;46(5):889-97.

98. Oguri M, Kato K, Hibino T, Yokoi K, Segawa T, Matsuo H, Watanabe S, Nozawa Y, Murohara T, Yamada Y. Identification of a polymorphism of UCP3 associated with recurrent in-stent restenosis of coronary arteries. Int J Mol Med. 2007;20(4):533-8.

99. Lv L, Ye W, Song P, Chen Y, Yang J, Zhang C, Chen X, Luo F. Relationship between ALDH2 genotype and in-stent restenosis in Chinese Han patients after percutaneous coronary intervention. BMC Cardiovasc Disord. 2019;19(1):176.

100. Pan CH, Chien SC, Chen CJ, Shih CM, Hsieh MH, Huang CY, Bi WF, Chan CS, Kao YT, Hsiao CY, et al. Circulating level of microRNA-142-5p is a potential biomarker for predicting in-stent restenosis: a case-control study. BMC Cardiovasc Disord. 2021;21(1):77.

101. Mendez-Barbero N, Gutierrez-Munoz C, Madrigal-Matute J, Minguez P, Egido J, Michel JB, Martin-Ventura JL, Esteban V, Blanco-Colio LM. A major role of TWEAK/Fn14 axis as a therapeutic target for post-angioplasty restenosis. EBioMedicine. 2019;46:274-89. 
102. Wang F, Su X, Liu C, Wu M, Li B. Prognostic value of plasma long noncoding RNA ANRIL for in-stent restenosis. Med Sci Monit. 2017:23:4733-9.

103. Ruedlinger J, Prado Y, Zambrano T, Saavedra N, Bobadilla B, Potthoff M, Perez L, Lanas F, Salazar LA. CYP2C19()2 polymorphism in chilean patients with in-stent restenosis development and controls. Biomed Res Int. 2017;2017:5783719.

104. Gabbasov ZA, Kozlov SG, Byazrova SV, Mel'nikov IS, Saburova OS. Relationship between the level of circulating CD45(+) platelets and development of restenosis after implantation of drug-eluting stents to patients with coronary heart disease. Bull Exp Biol Med. 2017;162(4):524-7.

105. Yu ZH, Wang HT, Tu C. Diagnostic value of microRNA-143 in predicting in-stent restenosis for patients with lower extremity arterial occlusive disease. Eur J Med Res. 2017;22(1):2.

106. Santulli G. microRNAs distinctively regulate vascular smooth muscle and endothelial cells: functional implications in angiogenesis, atherosclerosis, and in-stent restenosis. Adv Exp Med Biol. 2015:887:53-77.

107. Pleva L, Kovarova P, Faldynova L, Plevova P, Hilscherova S, Zapletalova J, Kusnierova P, Kukla P. The rs 1803274 polymorphism of the BCHE gene is associated with an increased risk of coronary in-stent restenosis. BMC Cardiovasc Disord. 2015:15:135.

108. Pleva L, Kusnierova P, Plevova P, Zapletalova J, Karpisek M, Faldynova L, Kovarova P, Kukla P. Increased levels of MMP-3, MMP-9 and MPO represent predictors of in-stent restenosis, while increased levels of ADMA, LCAT, ApoE and ApoD predict bare metal stent patency. Biomed Pap Med Fac Univ Palacky Olomouc Czech Repub. 2015;159(4):586-94.

109. Zhang Y, Wang Q, Yang D, Li D, Tang B, Yang Y, Ma S. Expression of mammalian target of rapamycin in atherosclerotic plaques is decreased under diabetic conditions: a mechanism for rapamycin resistance. Mol Med Rep. 2014;9(6):2388-92

110. Galluccio E, Piatti P, Citterio L, Lucotti PC, Setola E, Cassina L, Oldani M, Zavaroni I, Bosi E, Colombo A, et al. Hyperinsulinemia and impaired leptin-adiponectin ratio associate with endothelial nitric oxide synthase polymorphisms in subjects with in-stent restenosis. Am J Physiol Endocrinol Metab. 2008:294(5):E978-986.

111. Oguri M, Kato K, Hibino T, Yokoi K, Segawa T, Matsuo H, Watanabe S, Nozawa Y, Murohara T, Yamada Y. Genetic risk for restenosis after coronary stenting. Atherosclerosis. 2007;194(2):e172-178.

112. Ozben B, Diz-Kucukkaya R, Bilge AK, Hancer VS, Oncul A. The association of P-selectin glycoprotein ligand-1 VNTR polymorphisms with coronary stent restenosis. J Thromb Thrombolysis. 2007:23(3):181-7.

113. Gross CM, Kramer J, Pfeufer A, Dietz R, Gessner R, Praus M. The intron $6 \mathrm{G} / \mathrm{T}$ polymorphism of c-myb oncogene and the risk for coronary instent restenosis. Basic Res Cardiol. 2004;99(4):309-14.

114. Ribichini F, Ferrero V, Matullo G, Feola M, Vado A, Camilla T, Guarrera S, Carturan S, Vassanelli C, Uslenghi E, et al. Association study of the I/D polymorphism and plasma angiotensin-converting enzyme (ACE) as risk factors for stent restenosis. Clin Sci (Lond). 2004;107(4):381-9.

115. Hytonen J, Leppanen O, Braesen JH, Schunck WH, Mueller D, Jung F, Mrowietz C, Jastroch M, von Bergwelt-Baildon M, Kappert K, et al. Activation of peroxisome proliferator-activated receptor-delta as novel therapeutic strategy to prevent in-stent restenosis and stent thrombosis. Arterioscler Thromb Vasc Biol. 2016;36(8):1534-48.

116. Ryu SK, Cho EY, Park HY, Im EK, Jang YS, Shin GJ, Shim WH, Cho SY. Renin-angiotensin-aldosterone system (RAAS) gene polymorphism as a risk factor of coronary in-stent restenosis. Yonsei Med J. 2002:43(4):461-72.

117. Jorgensen E, Kelbaek H, Helqvist S, Jensen GV, Saunamaki K, Kastrup J, Havndrup O, Bundgaard H, Kyst Madsen J, Christiansen M, et al. Predic tors of coronary in-stent restenosis: importance of angiotensin-converting enzyme gene polymorphism and treatment with angiotensinconverting enzyme inhibitors. J Am Coll Cardiol. 2001;38(5):1434-9.

118. Harrison M, Siddiq A, Guildford A, Bone A, Santin M. Stent material surface and glucose activate mononuclear cells of control, type 1 and type 2 diabetes subjects. J Biomed Mater Res A. 2007;83(1):52-7.

119. Aliagaoglu C, Turan H, Erden I, Albayrak H, Ozhan H, Basar C, Gurlevik Z, Alcelik A. Relation of nickel allergy with in-stent restenosis in patients treated with cobalt chromium stents. Ann Dermatol. 2012;24(4):426-9.

120. Pons D, Monraats PS, Zwinderman AH, de Maat MP, Doevendans PA, de Winter RJ, Tio RA, Waltenberger J, Jukema JW. Metabolic background determines the importance of NOS3 polymorphisms in restenosis after percutaneous coronary intervention: a study in patients with and without the metabolic syndrome. Dis Markers. 2009;26(2):75-83.

121. Gutierrez-Carretero E, Mayoral-Gonzalez I, Jesus Moron F, FernandezQuero M, Dominguez-Rodriguez A, Ordonez A, Smani T. miR-30b-5p downregulation as a predictive biomarker of coronary in-stent restenosis. Biomedicines. 2021;9(4):354

122. Gao XF, Wang ZM, Chen AQ, Wang F, Luo S, Gu Y, Kong XQ, Zuo GF, Jiang XM, Ding GW, et al. Plasma small extracellular vesicle-carried miRNA-501-5p promotes vascular smooth muscle cell phenotypic modulation-mediated in-stent restenosis. Oxid Med Cell Longev. 2021:2021:6644970

123. Maheronnaghsh M, Niktab I, Enayati S, Amoli MM, Hosseini SK, Tavakkoly-Bazzaz J. Differentially expressed miR-152, a potential biomarker for in-stent restenosis (ISR) in peripheral blood mononuclear cells (PBMCs) of coronary artery disease (CAD) patients. Nutr Metab Cardiovasc Dis. 2021;31(4):1137-47.

124. Varela N, Lanas F, Salazar LA, Zambrano T. The current state of MicroRNAs as restenosis biomarkers. Front Genet. 2019;10:1247.

125. Räber L, Wohlwend L, Wigger M, Togni M, Wandel S, Wenaweser P, Cook S, Moschovitis A, Vogel R, Kalesan B, et al. Five-year clinical and angiographic outcomes of a randomized comparison of sirolimus-eluting and paclitaxel-eluting stents. Circulation. 2011;123(24):2819-28.

126. Moses JW, Leon MB, Popma JJ, Fitzgerald PJ, Holmes DR, O'Shaughnessy C, Caputo RP, Kereiakes DJ, Williams DO, Teirstein PS, et al. Sirolimuseluting stents versus standard stents in patients with stenosis in a native coronary artery. N Engl J Med. 2003;349(14):1315-23.

127. Park K, Park KW, Rha SW, Bae JH, Hur SH, Park JS, Yoon JH, Jang Y, Jeong $\mathrm{MH}$, Kim HS. Comparison of 5-year clinical outcomes between sirolimus-versus paclitaxel-eluting stent: Korean multicenter network analysis of 9000-patient cohort. Circ Cardiovasc Interv. 2012;5(2):174-84.

128. Suselbeck T, Latsch A, Siri H, Gonska B, Poerner T, Pfleger S, Schumacher $B$, Borggrefe M, Haase KK. Role of vessel size as a predictor for the occurrence of in-stent restenosis in patients with diabetes mellitus. Am J Cardiol. 2001:88(3):243-7.

129. Wang J-L, Qin Z, Wang Z-J, Shi D-M, Liu Y-Y, Zhao Y-X, Yang L-X, Cheng W-J, Zhou $Y$-J. New predictors of in-stent restenosis in patients with diabetes mellitus undergoing percutaneous coronary intervention with drug-eluting stent. J Geriatric Cardiol JGC. 2018;15(2):137-45.

130. Modi K, Soos MP, Mahajan K: Stent Thrombosis. In: StatPearls. Treasure Island (FL); 2022.

131. Yang WJ, Pan ZL, Zhang H, Pang LF, Guo Y, Chen KM. Evaluation of coronary artery in-stent restenosis with prospectively ECG-triggered axial CT angiography versus retrospective technique: a phantom study. Radiol Med. 2011;116(2):189-96.

132. Gao Y, Lu B, Hou ZH, Yu FF, Yin WH, Wang ZQ, Wu YJ, Mu CW, Meinel FG, McQuiston AD, et al. Coronary In-stent restenosis: assessment with corrected coronary opacification difference across coronary stents measured with CT angiography. Radiology. 2015;275(2):403-12.

133. Andreini D, Pontone G, Mushtaq S, Bartorelli AL, Bertella E, Trabattoni D, Montorsi P, Galli S, Foti C, Annoni A, et al. Coronary in-stent restenosis: assessment with $\mathrm{CT}$ coronary angiography. Radiology. 2012;265(2):410-7.

134. Sun Z, Almutairi AM. Diagnostic accuracy of 64 multislice CT angiography in the assessment of coronary in-stent restenosis: a meta-analysis. Eur J Radiol. 2010;73(2):266-73.

135. Sun Z, Davidson R, Lin CH. Multi-detector row CT angiography in the assessment of coronary in-stent restenosis: a systematic review. Eur J Radiol. 2009;69(3):489-95.

136. Sung S-H, Chen T-C, Cheng H-M, Lee J-C, Lang H-C, Chen C-H. Comparison of clinical outcomes in patients undergoing coronary intervention with drug-eluting stents or bare-metal stents: a nationwide population study. Acta Cardiologica Sinica. 2017;33(1):10-9.

137. Assali AR, Moustapha A, Sdringola S, Denktas AE, Willerson JT, Holmes DR Jr, Smalling RW. Acute coronary syndrome may occur with in-stent restenosis and is associated with adverse outcomes (The PRESTO Trial). Am J Cardiol. 2006;98(6):729-33.

138. Walters DL, Harding SA, Walsh CR, Wong P, Pomerantsev E, Jang I-K. Acute coronary syndrome is a common clinical presentation of in-stent restenosis. Am J Cardiol. 2002;89(5):491-4. 
139. Magalhaes MA, Minha S, Chen F, Torguson R, Omar AF, Loh JP, Escarcega RO, Lipinski MJ, Baker NC, Kitabata H, et al. Clinical presentation and outcomes of coronary in-stent restenosis across 3-stent generations. Circ Cardiovasc Interv. 2014;7(6):768-76.

140. Lee MS, Pessegueiro A, Zimmer R, Jurewitz D, Tobis J. Clinical presentation of patients with in-stent restenosis in the drug-eluting stent era. J Invasive Cardiol. 2008;20(8):401-3.

141. Jukema JW, Verschuren JJW, Ahmed TAN, Quax PHA. Restenosis after PCI. Part 1: pathophysiology and risk factors. Nat Rev Cardiol. 2012;9(1):53-62

142. Van Belle E, Bauters C, Hubert E, Bodart JC, Abolmaali K, Meurice T, McFadden EP, Lablanche JM, Bertrand ME. Restenosis rates in diabetic patients: a comparison of coronary stenting and balloon angioplasty in native coronary vessels. Circulation. 1997;96(5):1454-60.

143. Scheen AJ, Warzée F. Diabetes is still a risk factor for restenosis after drug-eluting stent in coronary arteries. Diabetes Care. 2004;27(7):1840-1.

144. Kaneda H, Ako J, Kataoka T, Takahashi T, Terashima M, Waseda K, Miyazawa A, Hassan A, Honda Y, Yock PG, et al. Heterogeneity of neointimal distribution of in-stent restenosis in patients with diabetes mellitus. Am J Cardiol. 2006;97(3):340-2.

145. Konishi Y, Ashikaga T, Sasaoka T, Kurihara K, Yoshikawa S, Isobe M. Comparison of outcomes after everolimus-eluting stent implantation in diabetic versus non-diabetic patients in the Tokyo-MD PCI study. J Cardiol. 2016:67(3):241-7.

146. D'Ascenzo F, Chieffo A, Cerrato E, Ugo F, Pavani M, Kawamoto H, di Summa R, Varbella F, Boccuzzi G, Omedè P, et al. Incidence and management of restenosis after treatment of unprotected left main disease with second-generation drug-eluting stents (from Failure in Left Main Study With 2nd Generation Stents-Cardiogroup III Study). Am J Cardiol. 2017;119(7):978-82

147. Honda Y, Muramatsu T, Ito Y, Sakai T, Hirano K, Yamawaki M, Araki M, Kobayashi N, Takimura H, Sakamoto Y, et al. Impact of ultra-long second-generation drug-eluting stent implantation. Catheter Cardiovasc Interv. 2016:87(2):E44-53.

148. Zheng C, Kang J, Park KW, Han J-K, Yang H-M, Kang H-J, Koo B-K, Kim $\mathrm{H}$-S. The predictors of target lesion revascularization and rate of in-stent restenosis in the second-generation drug-eluting stent era. J Interv Cardiol. 2019;2019:3270132.

149. Pi S-H, Rhee T-M, Lee JM, Hwang D, Park J, Park TK, Yang JH, Song YB, Choi J-H, Hahn J-Y, et al. Outcomes in patients with diabetes mellitus according to insulin treatment after percutaneous coronary intervention in the second-generation drug-eluting stent era. Am J Cardiol. 2018;121(12):1505-11.

150. Kuramitsu S, Ohya M, Shinozaki T, Otake H, Horie K, Kawamoto H, Yamanaka F, Natsuaki M, Shiomi H, Nakazawa G, et al. Risk factors and long-term clinical outcomes of second-generation drug-eluting stent thrombosis. Circ Cardiovasc Interv. 2019;12(6):e007822.

151. Kawecki D, Morawiec B, Dola J, Wańha W, Smolka G, Pluta A, Marcinkiewicz K, Ochała A, Nowalany-Kozielska E, Wojakowski W. Comparison of first- and second-generation drug-eluting stents in an all-comer population of patients with diabetes mellitus (from Katowice-Zabrze Registry). Med Sci Monit. 2015;21:3261-9.

152. De Luca G, Sauro R, Capasso M, Lanzillo T, Manganelli F, Carbone G, Lanni F, Pagliuca MR, Palmieri V, Serino V, et al. Impact of diabetes on the benefits from everolimus-eluting stent as compared to firstgeneration drug-eluting stent in patients with ST elevation myocardial infarction. Diabetes Vasc Dis Res. 2015;12(5):306-14

153. Kim W-J, Lee S-W, Park S-W, Kim Y-H, Yun S-C, Lee J-Y, Park D-W, Kang S-J, Lee CW, Lee J-H, et al. Randomized Comparison of everolimus-eluting stent versus sirolimus-eluting stent implantation for de novo coronary artery disease in patients with diabetes mellitus (ESSENCE-DIABETES). Circulation. 2011;124(8):886-92.

154. Kaul U, Bangalore S, Seth A, Arambam P, Abhaichand RK, Patel TM, Banker D, Abhyankar A, Mullasari AS, Shah S, et al. Paclitaxel-eluting versus everolimus-eluting coronary stents in diabetes. N Engl J Med. 2015;373(18):1709-19.

155. Kim YH, Her A-Y, Jeong MH, Kim B-K, Hong S-J, Kim S, Ahn C-M, Kim J-S, Ko Y-G, Choi D, et al. Effects of stent generation on clinical outcomes after acute myocardial infarction compared between prediabetes and diabetes patients. Sci Rep. 2021;11(1):9364
156. Zhang F, Dong L, Ge J. Meta-analysis of five randomized clinical trials comparing sirolimus- versus paclitaxel-eluting stents in patients with diabetes mellitus. Am J Cardiol. 2010;105(1):64-8.

157. Tomai F, Reimers B, De Luca L, Galassi AR, Gaspardone A, Ghini AS, Ferrero V, Favero L, Gioffrè G, Prati F, et al. Head-to-head comparison of sirolimus- and paclitaxel-eluting stent in the same diabetic patient with multiple coronary artery lesions. A prospective, randomized, multicenter study. Diabetes Care. 2008;31(1):15-9.

158. Alfonso F, Cuesta J, Pérez-Vizcayno MJ, García Del Blanco B, Rumoroso JR, Bosa F, Pérez de Prado A, Masotti M, Moreno R, Cequier A, et al. Bioresorbable vascular scaffolds for patients with in-stent restenosis: the RIBS VI study. JACC Cardiovasc Interv. 2017;10(18):1841-51.

159. Jeger RV, Farah A, Ohlow M-A, Mangner N, Möbius-Winkler S, Weilenmann D, Wöhrle J, Stachel G, Markovic S, Leibundgut G, et al. Long-term efficacy and safety of drug-coated balloons versus drugeluting stents for small coronary artery disease (BASKET-SMALL 2): 3-year follow-up of a randomised, non-inferiority trial. The Lancet. 2020;396(10261):1504-10.

160. Megaly M, Ali A, Abraham B, Khalil C, Zordok M, Shaker M, Tawadros M, Hennawy BS, Elbadawi A, Omer M, et al. Outcomes with drug-coated balloons in percutaneous coronary intervention in diabetic patients. Cardiovasc Revasc Med. 2020;21(1):78-85.

161. Alfonso F, Perez-Vizcayno MJ, Cardenas A, Garcia Del Blanco B, Seidelberger B, Iniguez A, Gomez-Recio M, Masotti M, Velazquez MT, Sanchis $J$, et al. A randomized comparison of drug-eluting balloon versus everolimus-eluting stent in patients with bare-metal stent-in-stent restenosis: the RIBS V Clinical Trial (Restenosis Intra-stent of Bare Metal Stents: paclitaxel-eluting balloon vs. everolimus-eluting stent). J Am Coll Cardiol. 2014:63(14):1378-86.

162. Baan J Jr, Claessen BE, Dijk KB, Vendrik J, van der Schaaf RJ, Meuwissen M, van Royen N, Gosselink ATM, van Wely MH, Dirkali A, et al. A randomized comparison of paclitaxel-eluting balloon versus everolimuseluting stent for the treatment of any in-stent restenosis: the DARE trial. JACC Cardiovasc Interv. 2018;11(3):275-83.

163. Claessen BE, Henriques JPS, Vendrik J, Boerlage-van Dijk K, van der Schaaf RJ, Meuwissen M, van Royen N, Gosselink ATM, van Wely MH, Dirkali A, et al. Paclitaxel-eluting balloon versus everolimus-eluting stent in patients with diabetes mellitus and in-stent restenosis: insights from the randomized DARE trial. Catheter Cardiovasc Interv. 2019;93(2):216-21.

164. Armstrong EJ, Waltenberger J, Rogers JH. Percutaneous coronary intervention in patients with diabetes: current concepts and future directions. J Diabetes Sci Technol. 2014;8(3):581-9.

165. Codner P, Gurm HS, Motivala A. Coronary stents in diabetic patients: state of the knowledge. Curr Cardiol Rep. 2017;19(4):28.

166. Bangalore S, Kumar S, Fusaro M, Amoroso N, Kirtane AJ, Byrne RA, Williams DO, Slater J, Cutlip DE, Feit F. Outcomes with various drug eluting or bare metal stents in patients with diabetes mellitus: mixed treatment comparison analysis of 22,844 patient years of follow-up from randomised trials. BMJ. 2012;345:e5170.

167. Bundhun PK, Bhurtu A, Soogund MZ, Long MY. Comparing the clinical outcomes between drug eluting stents and bare metal stents in patients with insulin-treated type 2 diabetes mellitus: a systematic review and meta-analysis of 10 randomized controlled trials. PLoS ONE. 2016;11(4):e0154064.

168. Poder TG, Erraji J, Coulibaly LP, Koffi K. Percutaneous coronary intervention with second-generation drug-eluting stent versus baremetal stent: Systematic review and cost-benefit analysis. PLoS ONE. 2017;12(5):e0177476.

169. Graham G. Disparities in cardiovascular disease risk in the United States. Curr Cardiol Rev. 2015;11(3):238-45.

170. McMaughan DJ, Oloruntoba O, Smith ML. Socioeconomic status and access to healthcare: interrelated drivers for healthy aging. Front Public Health. 2020;8:231.

171. Riley WJ. Health disparities: gaps in access, quality and affordability of medical care. Trans Am Clin Climatol Assoc. 2012;123:167-72.

172. Kreatsoulas C, Anand SS. The impact of social determinants on cardiovascular disease. Can J Cardiol. 2010;26(Suppl C):8C-13C.

173. Hill-Briggs F, Adler NE, Berkowitz SA, Chin MH, Gary-Webb TL, NavasAcien A, Thornton PL, Haire-Joshu D. Social determinants of health and diabetes: a scientific review. Diabetes Care. 2020:44:258. 
174. Beckles GL, Chou CF. Disparities in the prevalence of diagnosed diabetes-United States, 1999-2002 and 2011-2014. MMWR Morb Mortal Wkly Rep. 2016;65(45):1265-9.

175. Garg P, Normand S-LT, Silbaugh TS, Wolf RE, Zelevinsky K, Lovett A, Varma MR, Zhou Z, Mauri L. Drug-eluting or bare-metal stenting in patients with diabetes mellitus. Circulation. 2008;118(22):2277-85.

176. Fujita T, Takeda T, Tsujino Y, Yamaji M, Sakaguchi T, Maeda K, Mabuchi $H$, Murakami T, Morimoto T, Kimura T. Effect of glycemic control during follow-up on late target lesion revascularization after implantation of new-generation drug-eluting stents in patients with diabetes- a singlecenter observational study. Circ Rep. 2020;2(9):479-89.

177. Sasso FC, Rinaldi L, Lascar N, Marrone A, Pafundi PC, Adinolfi LE, Marfella $\mathrm{R}$. Role of tight glycemic control during acute coronary syndrome on CV outcome in type 2 diabetes. J Diabetes Res. 2018;2018:3106056.

178. Kornowski R, Fuchs S. Optimization of glycemic control and restenosis prevention in diabetic patients undergoing percutaneous coronary interventions. J Am Coll Cardiol. 2004;43(1):15-7.

179. Corpus RA, George PB, House JA, Dixon SR, Ajluni SC, Devlin WH, Timmis GC, Balasubramaniam M, O'Neill WW. Optimal glycemic control is associated with a lower rate of target vessel revascularization in treated type II diabetic patients undergoing elective percutaneous coronary intervention. J Am Coll Cardiol. 2004:43(1):8-14.

180. Yang CD, Shen Y, Lu L, Yang ZK, Hu J, Zhang RY, Shen WF, Ding FH, Wang $\mathrm{XQ}$. Visit-to-visit HbA1c variability is associated with in-stent restenosis in patients with type 2 diabetes after percutaneous coronary intervention. Cardiovasc Diabetol. 2020;19(1):133

181. Piatti P, Di Mario C, Monti LD, Fragasso G, Sgura F, Caumo A, Setola E, Lucotti P, Galluccio E, Ronchi C, et al. Association of insulin resistance, hyperleptinemia, and impaired nitric oxide release with in-stent restenosis in patients undergoing coronary stenting. Circulation. 2003:108(17):2074-81

182. Sasso FC, Pafundi PC, Marfella R, Calabro P, Piscione F, Furbatto F, Esposito G, Galiero R, Gragnano F, Rinaldi L, et al. Adiponectin and insulin resistance are related to restenosis and overall new $\mathrm{PCl}$ in subjects with normal glucose tolerance: the prospective AIRE Study. Cardiovasc Diabetol. 2019:18(1):24.

183. Feola M, Ribichini F, Ferrero V, Procopio M, Magro G, Vado A, Borretta G, Boccuzzi G, Vassanelli C, Uslenghi E. Comparison of frequency of insulin resistance after coronary stenting in patients with type 2 diabetes mellitus with versus without coronary restenosis. Am J Cardiol. 2004;94(6):777-80.

184. Nishio K, Fukui T, Tsunoda F, Kawamura K, Itoh S, Konno N, Ozawa K, Katagiri T. Insulin resistance as a predictor for restenosis after coronary stenting. Int J Cardiol. 2005;103(2):128-34.

185. Komatsu T, Yaguchi I, Komatsu S, Nakahara S, Kobayashi S, Sakai Y, Taguchi I. Impact of insulin resistance on neointimal tissue proliferation after 2nd-generation drug-eluting stent implantation. Tex Heart Inst J. 2015;42(4):327-32.

186. Sekiguchi M, Kurabayashi M, Adachi H, Hoshizaki H, Oshima S, Taniguchi K. Usefulness of insulin resistance measured by homeostasis model assessment in predicting restenosis after coronary stent placement in nondiabetic patients. Am J Cardiol. 2004;93(7):920-2.

187. Hwang IK, Kim YK, Rha SW, Ra JE, Seo BS, Lee JK, Na JO, Choi CU, Lim HE, Han SW, et al. Impact of insulin resistance on 1-year clinical outcomes in non-diabetic patients undergoing percutaneous coronary intervention with drug-eluting stents. J Cardiol. 2013;61(2):113-6.

188. Armstrong EJ, McCabe JM. Insulin resistance and in-stent restenosis: could modulating insulin improve outcomes of percutaneous coronary intervention? Coron Artery Dis. 2015;26(1):1-2.

189. Mone P, Gambardella J, Minicucci F, Lombardi A, Mauro C, Santulli G. Hyperglycemia drives stent restenosis in STEMI patients. Diabetes Care. 2021:44(11):e192-3.

190. Cassese S, Ndrepepa G, Kufner S, Byrne RA, Giacoppo D, Ott I, Laugwitz KL, Schunkert H, Kastrati A, Fusaro M. Drug-coated balloon angioplasty for in-stent restenosis of femoropopliteal arteries: a meta-analysis. Eurolntervention. 2017;13(4):483-9.

191. Nasr B, Crespy V, Penasse E, Gaudry M, Rosset E, Feugier P, Goueffic Y, Maurel B, Hostalrich A, Alric $P$ et al. Late outcomes of carotid artery stenting for radiation therapy-induced carotid stenosis. J Endovasc Ther. 2022:15266028211068757.
192. Huang H, Wu L, Guo Y, Zhang Y, Zhao J, Yu Z, Luo X. Treatment of the carotid in-stent restenosis: a systematic review. Front Neurol. 2021;12:748304.

193. Domingo RA, Ravindran K, Tawk RG, Endovascular Neurosurgery Research G. Carotid in-stent stenosis: cutting balloon angioplasty: 2-dimensional operative video. Oper Neurosurg (Hagerstown). 2021;21(3):E240-1.

194. Inomata Y, Hanaoka Y, Koyama JI, Suzuki Y, Fujii Y, Ogiwara T, Horiuchi T. Endovascular revascularization with a scoring balloon for carotid in-stent restenosis: case report and literature review. Clin Neuroradiol. 2021;31(4):1199-204

195. Zhen Y, Ren H, Chen J, Chang Z, Wang C, Zheng J. Systematic review and meta-analysis of drug-coated balloon for in-stent restenosis in femoropopliteal artery disease. J Vasc Interv Radiol 2021.

196. Liu MY, Li W, Guo X, Zhang Z, Liu B, Yu H, Zhang Z, Chen X, Feng H. Percutaneous mechanical atherectomy plus thrombectomy using the Rotarex(R)S device followed by a drug-coated balloon for the treatment of femoropopliteal artery in-stent restenosis: a prospective single-center, single-arm efficacy trial (PERMIT-ISR Trial). Front Surg. 2021:8:671849.

197. Kurata N, lida O, Takahara M, Asai M, Masuda M, Okamoto S, Ishihara T, Nanto K, Mano T. Predictive factors for restenosis following stentsupported endovascular therapy with intravascular ultrasound evaluation for femoropopliteal chronic total occlusion. J Vasc Interv Radiol. 2021;32(5):712-20.

198. Tomoi Y, Soga Y, Okazaki J, lida O, Shiraki T, Hiramori S, Ando K. Drugcoated stent implantation vs bypass surgery for in-stent occlusion after femoropopliteal stenting. Heart Vessels. 2021;36(5):646-53.

199. Bosiers M, Deloose K, Callaert J, Verbist J, Hendriks J, Lauwers P, Schroe $H$, Lansink W, Scheinert D, Schmidt A, et al. Stent-grafts are the best way to treat complex in-stent restenosis lesions in the superficial femoral artery: 24-month results from a multicenter randomized trial. J Cardiovasc Surg (Torino). 2020;61(5):617-25.

200. Sugimoto M, Komori K, Yokoi H, Ohki T, Kichikawa K, Nakamura M, Nanto S, O'Leary EE, Lottes AE, Saunders AT, et al. Long-term effectiveness of a drug-eluting stent for femoropopliteal in-stent restenosis: subanalysis of the zilver PTX Japan post-market surveillance study. J Endovasc Ther. 2021;28(2):229-35.

201. Doshi R, Kumar A, Adalja D, Vaz I, Shariff M. Meta-analysis of usefulness of drug coated balloon versus standard balloon in the treatment of femoropopliteal in-stent-restenosis. Am J Cardiol. 2020;133:170-1.

202. Bekken JA, Geensen R, Kok R, Kuijper M, de Vries JPM, Fioole B. Covered stents vs. angioplasty for common iliac artery in stent restenosis: a retrospective comparison. Eur J Vasc Endovasc Surg 2021.

203. Saleem T, Raju S. An overview of in-stent restenosis in iliofemoral venous stents. J Vasc Surg Venous Lymphat Disord 2021.

204. Tran MA, Lakhanpal P, Lakhanpal S, Satwah VK, Lakhanpal G, Pappas PJ. Type of anti-thrombotic therapy for venous stenting in patients with non-thrombotic iliac vein lesions does not influence the development of in-stent restenosis. Phlebology. 2020;35(10):805-13.

205. Vertes M, Juhasz IZ, Nguyen TD, Veres DS, Huttl A, Nemes B, Huttl K, Dosa E. Stent protrusion $>20 \mathrm{~mm}$ into the aorta: a new predictor for restenosis after kissing stent reconstruction of the aortoiliac bifurcation. J Endovasc Ther. 2018;25(5):632-9.

206. Ho KJ, Devlin PM, Madenci AL, Semel ME, Gravereaux EC, Nguyen LL, Belkin M, Menard MT. High dose-rate brachytherapy for the treatment of lower extremity in-stent restenosis. J Vasc Surg. 2017;65(3):734-43.

207. Colombo M, He Y, Corti A, Gallo D, Ninno F, Casarin S, Rozowsky JM, Migliavacca F, Berceli S, Chiastra C. In-stent restenosis progression in human superficial femoral arteries: dynamics of lumen remodeling and impact of local hemodynamics. Ann Biomed Eng. 2021;49(9):2349-64.

208. Yanaka K, Konishi A, Shinke T, Kozuki A, Kawamori H, Tsukiyama Y, lida O, Kadotani M, Omori T, Hirata Kl. Open-label multicenter registry on the outcomes of in-stent restenosis treated by balloon angioplasty with optical frequency domain imaging in the superficial femoral artery (ISLAND-SFA Study). Ann Vasc Dis. 2020;13(3):291-9.

209. Yang YB, Shen J, Wang SH, Song JB, Ge F, Xie JP, Qu JS, Mao XZ, Kuang $Z C$, Shang $N$, et al. A risk predictor of restenosis after superficial femoral artery stent implantation: relevance of mean platelet volume. BMC Cardiovasc Disord. 2020;20(1):361 
210. Stone D. A literature review of the efficacy of debulking devices for in-stent restenosis of the femoropopliteal artery. J Vasc Surg. 2020:72(1):367.

211. Davies MG, Saad WE. Impact of elevated perioperative fasting blood glucose on carotid artery stenting outcomes. Ann Vasc Surg. 2014;28(8):1885-91.

212. Aronson D. Restenosis in diabetic patients: is hyperinsulinemia the culprit? Circulation. 1996;94(11):3003-5.

213. Zhao LP, Xu WT, Wang L, Li H, Shao CL, Gu HB, Chan SP, Xu HF, Yang $\mathrm{XJ}$. Influence of insulin resistance on in-stent restenosis in patients undergoing coronary drug-eluting stent implantation after long-term angiographic follow-up. Coron Artery Dis. 2015;26(1):5-10.

214. Hong SJ, Kim MH, Ahn TH, Ahn YK, Bae JH, Shim WJ, Ro YM, Lim DS. Multiple predictors of coronary restenosis after drug-eluting stent implantation in patients with diabetes. Heart. 2006;92(8):1119-24.

215. Costa YC, Mauro V, Fairman E, Charask A, Olguin L, Caceres L, Barrero C. Prognostic value of insulin resistance assessed by HOMA-IR in nondiabetic patients with decompensated heart failure. Curr Probl Cardiol 2022:101112.

216. Adam TC, Drummen M, Macdonald I, Jalo E, Siig-Vestentoft $P$, Martinez JA, Handjiev-Darlenska T, Brand-Miller J, Poppitt S, Stratton G, et al. Association of psychobehavioral variables with $\mathrm{HOMA}-\mathrm{IR}$ and $\mathrm{BMI}$ differs for men and women with prediabetes in the PREVIEW lifestyle intervention. Diabetes Care. 2021;44(7):1491-8.

217. Watanabe M, Risi R, Camajani E, Contini S, Persichetti A, Tuccinardi D, Ernesti I, Mariani S, Lubrano C, Genco A, et al. Baseline HOMA IR and circulating FGF21 levels predict NAFLD improvement in patients undergoing a low carbohydrate dietary intervention for weight loss: a prospective observational pilot study. Nutrients. 2020;12(7):2141.

218. Peng PS, Kao TW, Chang PK, Chen WL, Peng PJ, Wu LW. Association between HOMA-IR and Frailty among U.S. Middle-aged and Elderly Population. Sci Rep. 2019;9(1):4238.

219. Wallace TM, Levy JC, Matthews DR. Use and abuse of HOMA modeling. Diabetes Care. 2004;27(6):1487-95.

220. Imazu M, Sumii K, Yamamoto H, Toyofuku M, Okimoto T, Gomyo Y, Ueda $\mathrm{H}$, Hayashi $Y$, Kohno N. Hyperinsulinemia as a risk factor for restenosis after coronary balloon angioplasty. Jpn Circ J. 2001;65(11):947-52.

221. Shoukry A, El-Sherbieny I, Swelam E. Association of insulin resistance, insulin and leptin levels with coronary in-stent restenosis. Egypt Heart J. 2012;64(1):35-42.

222. Williams WT, Assi R, Hall MR, Protack CD, Lu DY, Wong DJ, Vasilas P, Dardik A. Metabolic syndrome predicts restenosis after carotid endarterectomy. J Am Coll Surg. 2014;219(4):771-7.

223. Gilbert J, Raboud J, Zinman B. Meta-analysis of the effect of diabetes on restenosis rates among patients receiving coronary angioplasty stenting. Diabetes Care. 2004;27(4):990-4

224. McGill JB, Schneider DJ, Arfken CL, Lucore CL, Sobel BE. Factors responsible for impaired fibrinolysis in obese subjects and NIDDM patients. Diabetes. 1994;43(1):104-9.

225. Ray KK, Seshasai SRK, Wijesuriya S, Sivakumaran R, Nethercott S, Preiss D, Erqou S, Sattar N. Effect of intensive control of glucose on cardiovascular outcomes and death in patients with diabetes mellitus: a meta-analysis of randomised controlled trials. The Lancet. 2009;373(9677):1765-72.

226. Peuler JD, Phare SM, lannucci AR, Hodorek MJ. Differential inhibitory effects of antidiabetic drugs on arterial smooth muscle cell proliferation. Am J Hypertens. 1996;9(2):188-92.

227. Law RE, Meehan WP, Xi XP, Graf K, Wuthrich DA, Coats W, Faxon D, Hsueh WA. Troglitazone inhibits vascular smooth muscle cell growth and intimal hyperplasia. J Clin Investig. 1996:98(8):1897-905.

228. Santulli G, Dridi H, Gambardella J, Jankauskas SS, Yuan Q, et al. IP3 receptor orchestrates maladaptive vascular responses in heart failure. J Clin Investig. 2022; in press.

229. Choi D, Kim SK, Choi SH, Ko YG, Ahn CW, Jang Y, Lim SK, Lee HC, Cha BS. Preventative effects of rosiglitazone on restenosis after coronary stent implantation in patients with type 2 diabetes. Diabetes Care. 2004;27(11):2654-60.

230. Geng D-f, Jin D-m, Wu W, Wang Z, Wang J-f. Effect of thiazolidinediones on in-stent restenosis in patients after coronary stenting: a meta-analysis of randomized controlled trials. Atherosclerosis. 2009;202(2):521-8.
231. Garcia-Garcia HM, Garg S, Brugaletta S, Morocutti G, Ratner RE, Kolatkar NS, Kravitz BG, Miller DM, Huang C, Nesto RW, et al. Evaluation of in-stent restenosis in the APPROACH trial (assessment on the prevention of progression by rosiglitazone on atherosclerosis in diabetes patients with cardiovascular history). Int J Cardiovasc Imaging. 2012;28(3):455-65.

232. Zhao SJ, Zhong ZS, Qi GX, Shi LY, Chen L, Tian W. Effect of pioglitazone in preventing in-stent restenosis after percutaneous coronary intervention in patients with type 2 diabetes: a meta-analysis. PLOS ONE. 2016;11(5):e0155273.

233. Chaitman BR, Hardison RM, Adler D, Gebhart S, Grogan M, Ocampo S, Sopko G, Ramires JA, Schneider D, Frye RL, et al. The bypass angioplasty revascularization investigation 2 diabetes randomized trial of different treatment strategies in type 2 diabetes mellitus with stable ischemic heart disease. Circulation. 2009;120(25):2529-40.

234. Inzucchi SE, Masoudi FA, Wang Y, Kosiborod M, Foody JM, Setaro JF, Havranek EP, Krumholz HM. Insulin-sensitizing antihyperglycemic drugs and mortality after acute myocardial infarction. Insights Natl Heart Care Project. 2005;28(7):1680-9.

235. Kastrati A, Cassese S. In-stent restenosis in the United States: time to enrich its treatment armamentarium. J Am Coll Cardiol. 2020;76(13):1532-5.

236. Rogers KC, Faircloth JM, Finks SW. Use of cilostazol in percutaneous coronary interventions. Ann Pharmacother. 2012;46(6):839-50.

237. Singh I, Shafiq N, Pandhi P, Reddy S, Pattanaik S, Sharma Y, Malhotra S. Triple antiplatelet therapy vs. dual antiplatelet therapy in patients undergoing percutaneous coronary intervention: an evidencebased approach to answering a clinical query. $\mathrm{Br} J$ Clin Pharmacol. 2009:68(1):4-13.

238. Brown DL, Levine DA, Albright K, Kapral MK, Leung LY, Reeves MJ, Sico J, Strong B, Whiteley WN, American Heart Association Stroke C. Benefits and risks of dual versus single antiplatelet therapy for secondary stroke prevention: a systematic review for the 2021 guideline for the prevention of stroke in patients with stroke and transient ischemic attack. Stroke. 2021;52(7):e468-79.

239. Smith SA, Newby AC, Bond M. Ending restenosis: inhibition of vascular smooth muscle cell proliferation by CAMP. Cells. 2019;8(11):1447.

240. Lee S-W, Park S-W, Kim Y-H, Yun S-C, Park D-W, Lee CW, Hong M-K, Kim H-S, Ko J-K, Park J-H, et al. Drug-eluting stenting followed by cilostazol treatment reduces late restenosis in patients with diabetes mellitus: the DECLARE-DIABETES trial (a randomized comparison of triple antiplatelet therapy with dual antiplatelet therapy after drugeluting stent implantation in diabetic patients). J Am Coll Cardiol. 2008;51(12):1181-7.

241. Deftereos S, Giannopoulos G, Raisakis K, Kossyvakis C, Kaoukis A, Panagopoulou V, Driva M, Hahalis G, Pyrgakis V, Alexopoulos D, et al. Colchicine treatment for the prevention of bare-metal stent restenosis in diabetic patients. J Am Coll Cardiol. 2013;61(16):1679-85.

242. Yokoi H, Daida H, Kuwabara Y, Nishikawa H, Takatsu F, Tomihara H, Nakata Y, Kutsumi Y, Ohshima S, Nishiyama S, et al. Effectiveness of an antioxidant in preventing restenosis after percutaneous transluminal coronary angioplasty: the probucol angioplasty restenosis trial. J Am Coll Cardiol. 1997:30(4):855-62.

243. Moustapha A, Assali AR, Sdringola S, Vaughn WK, Fish RD, Rosales O, Schroth G, Krajcer Z, Smalling RW, Anderson HV. Percutaneous and surgical interventions for in-stent restenosis: long-term outcomes and effect of diabetes mellitus. J Am Coll Cardiol. 2001;37(7):1877-82.

244. Gruberg L, Waksman R, Ajani AE, Kim HS, White RL, Pinnow EE, Satler LF, Pichard AD, Kent KM, Lindsay J Jr. The effect of intracoronary radiation for the treatment of recurrent in-stent restenosis in patients with diabetes mellitus. J Am Coll Cardiol. 2002;39(12):1930-6.

245. Moses JW, Moussa I, Leon MB, Teirstein PS, Fish RD, Ellis SG, Nawas D, Kluck B, Giorgianni JA, Donohoe D, et al. Effect of catheter-based iridium-192 gamma brachytherapy on the added risk of restenosis from diabetes mellitus after intervention for in-stent restenosis (subanalysis of the GAMMA I Randomized Trial). Am J Cardiol. 2002;90(3):243-7.

246. lakovou I, Mehran R, Dangas G, Lansky AJ, Stone GW, Mintz GS, Aymong E, Ashby DT, Pichard AD, Satler LF, et al. Favorable effect of gammaradiation for in-stent restenosis: effect of diabetes on angiographic and clinical outcomes. Catheter Cardiovasc Interv. 2004;62(3):303-7. 
247. Lu L, Wang YN, Sun WH, Liu ZH, Zhang Q, Pu L, Yang K, Wang LJ, Zhu $\mathrm{ZB}$, Meng $\mathrm{H}$, et al. Two-dimensional fluorescence in-gel electrophoresis of coronary restenosis tissues in minipigs: increased adipocyte fatty acid binding protein induces reactive oxygen species-mediated growth and migration in smooth muscle cells. Arterioscler Thromb Vasc Biol. 2013;33(3):572-80.

248. Varzideh F, Jankauskas SS, Kansakar U, Mone P, Gambardella J, Santulli G. Sortilin drives hypertension by modulating sphingolipid/ceramide homeostasis and by triggering oxidative stress. J Clin Investig. 2022; in press.

249. Münzel T, Camici GG, Maack C, Bonetti NR, Fuster V, Kovacic JC. Impact of oxidative stress on the heart and vasculature: part 2 of a 3-part series. J Am Coll Cardiol. 2017;70(2):212-29.

250. Liu J, Li M, Lu H, Qiao W, Xi D, Luo T, Xiong H, Guo Z. Effects of probucol on restenosis after percutaneous coronary intervention: a systematic review and meta-analysis. PLoS ONE. 2015;10(4):e0124021-e0124021.

\section{Publisher's Note}

Springer Nature remains neutral with regard to jurisdictional claims in published maps and institutional affiliations.

- fast, convenient online submission

- thorough peer review by experienced researchers in your field

- rapid publication on acceptance

- support for research data, including large and complex data types

- gold Open Access which fosters wider collaboration and increased citations

- maximum visibility for your research: over $100 \mathrm{M}$ website views per year

At BMC, research is always in progress.

Learn more biomedcentral.com/submissions 